\title{
Gunshot call production by the North Pacific right whale Eubalaena japonica in the southeastern Bering Sea
}

\author{
Jessica L. Crance ${ }^{1, *}$, Catherine L. Berchok ${ }^{1}$, Jennifer L. Keating ${ }^{2}$ \\ ${ }^{1}$ Marine Mammal Laboratory, AFSC/NMFS/NOAA, 7600 Sand Point Way NE, Seattle, WA 98115, USA \\ ${ }^{2}$ Marine Mammal and Turtle Division, SWFSC/NMFS/NOAA, 8901 La Jolla Shores Dr., La Jolla, CA 92037-1508, USA
}

\begin{abstract}
During dedicated surveys for the Critically Endangered eastern stock of North Pacific right whales Eubalaena japonica (NPRW) in the Bering Sea, focal follows (FFs) were combined with passive acoustic monitoring to correlate vocal activity with dive behavior. During FFs, impulsive gunshot calls (hereafter 'gunshots'), similar to those produced by other right whale populations, were localized to male and female NPRWs. The timing of gunshots correlated strongly with diving behavior observed during the FFs. Log survivorship analysis of inter-blow intervals showed a bout criterion interval of $40 \mathrm{~s}$, separating the data into shorter surfacings and longer dives. For both, gunshots were skewed closer to the end of the sequence (modal gunshot to blow times: $5 \mathrm{~s}$ for dives, $7 \mathrm{~s}$ for surfacings) than the beginning (modal blow to gunshot times: $22 \mathrm{~s}$ for dives, $13 \mathrm{~s}$ for surfacings). Gunshots were more commonly produced during dives than surfacings. Mean gunshot calling rate during FFs was 133.0 calls h$^{-1}$ (range: 38.9-425.0). Other NPRW calls, including upcalls, the predominant call used to identify right whales acoustically, were not detected during the FFs. To determine comparative call detection rates, an additional $180 \mathrm{~h}$ of non-FF recordings were analyzed. Gunshots were detected $~ 50$ times more frequently than upcalls (mean: 228.3 vs. 4.3 calls h$^{-1}$, respectively), with a maximum gunshot calling rate of 835.7 calls $^{-1}$. This is the first study to definitively attribute gunshots to NPRW, and demonstrates the importance of including gunshots in passive acoustic studies, which will greatly increase NPRW detectability while supporting more accurate determinations of their spatio-temporal distribution.
\end{abstract}

KEY WORDS: Right whale $\cdot$ Passive acoustics $\cdot$ Gunshot call $\cdot$ Upcall $\cdot$ Communication $\cdot$ Focal follow

\section{INTRODUCTION}

North Pacific right whales Eubalaena japonica were extensively hunted by sail-based 'Yankee' whalers beginning in 1835, and an estimated 26000 to 37000 whales (ca. $80 \%$ of the population) were killed within 2 decades (Scarff 2001). By 1900, they were essentially commercially extinct, although very low levels of catches continued for many years. Two populations, eastern and western, are recognized, and both were highly depleted by whaling (Clapham et al. 2004). By 1960, the frequency of sightings suggested that these populations were beginning to make a slow recovery;

${ }^{*}$ Corresponding author: jessica.crance@noaa.gov however, both became the target of illegal whaling by the USSR in the 1960s. An estimated 516 right whales were killed by Soviet whaling fleets in the eastern North Pacific between 1962 and 1968 (Ivashchenko \& Clapham 2012, Ivashchenko et al. in press), and it appears likely this represented the bulk of that remnant population. Today, the Critically Endangered eastern stock (hereafter NPRW; Reilly et al. 2008) is estimated at only about 30 animals (Wade et al. 2011); while this estimate may refer to a sub-population inhabiting the southeastern Bering Sea (SEBS), the extreme paucity of recent sightings elsewhere makes it unlikely that the overall population is significantly larger.

(C) Outside the USA the US Government 2017. Open Access under Creative Commons by Attribution Licence. Use, distribution and reproduction are unrestricted. Authors and original publication must be credited.

Publisher: Inter-Research · www.int-res.com 
Numerous studies have described sound production by North Atlantic right whales E. glacialis (NARW) and southern right whales E. australis (SRW). A variety of call types have been documented, including upcalls, gunshot calls (hereafter 'gunshots'), and non-stereotyped tonal calls (e.g. screams and warbles). The upcall is one of the most frequently used call types in acoustic studies of NARW and SRW, given its stereotyped nature and its use by all age and sex classes (Cummings et al. 1972, Clark 1982, 1984, Matthews et al. 2001, Wright 2001, Vanderlaan et al. 2003, Parks \& Tyack 2005, Parks et al. 2005, 2011). Although upcalls, variations of down-up calls, and tonal calls have been attributed to NPRW (McDonald \& Moore 2002, Mellinger 2004, Munger et al. 2005), the full acoustic repertoire has yet to be described for this species. Upcalls have been frequently used in auto-detection analyses, and have been the default call type for past NPRW studies (McDonald \& Moore 2002, Waite et al. 2003, Mellinger et al. 2004, 2007, Wiggins et al. 2004, Munger et al. 2005, 2008, 2011, Urazghildiiev \& Clark 2007, Marques et al. 2011). However, on a dedicated NPRW survey in the SEBS in 2008, gunshots dominated the acoustic recordings, making it clear that this call type needed further investigation within this population.

The gunshot, originally referred to as an 'underwater slap' in early literature, is a call type that has been reported for both NARW and SRW (e.g. Cummings et al. 1974, Clark 1982, 1983, 1984, Matthews et al. 2001, Parks \& Tyack 2005, Parks et al. 2005, 2011, 2012). Gunshots have been described as short, broadband impulsive sounds ranging in frequency from $20 \mathrm{~Hz}$ to $20 \mathrm{kHz}$, with a short duration of approximately $200 \mathrm{~ms}$ (e.g. Matthews et al. 2001, Laurinolli et al. 2003, Parks \& Tyack 2005). The gunshot appears to be produced internally, with no observed concurrent surface impact or movement of flippers, flukes, or jaws (Clark 1983, Parks et al. 2005). In both NARW and SRW, the gunshot is typically produced less frequently than the upcall and other tonal calls at their feeding or calving grounds (Clark 1982, 1983, 1984, Matthews et al. 2001, Parks et al. 2005, 2011), although this is often season- or location-dependent (i.e. gunshots were reported as the predominant call type in the Bay of Fundy in mid-July and August; Laurinolli et al. 2003, Van Parijs et al. 2009). In SRW, gunshots have been reported to be produced by adults of both sexes, as well as by a young adult, in the context of what was interpreted as an aggressive behavior (Clark 1983). In the North Atlantic, Parks et al. $(2005,2011,2012)$ attributed gunshots to adult males who produce this call type most often in mid- summer and early fall, right before the breeding season, leading the authors to hypothesize that gunshot bouts may function as a reproductive advertisement signal. Recently, E. Gerstein et al. (pers. comm.) attributed gunshot production to female NARW, and hypothesized that it served as maternal communication or as an indicator of stress. Although a few more recent NPRW studies have included gunshots in their analyses (e.g. Miksis-Olds et al. 2010, Stafford et al. 2010), these studies were based upon long-term autonomous recorder data without any concurrent visual observation.

The Alaska Fisheries Science Center/Marine Mammal Laboratory (AFSC/MML) conducted dedicated NPRW surveys from 2007 to 2010 in the SEBS with the goal of collecting photographs and biopsy samples, as well as deploying satellite telemetry tags to determine movement and migration patterns. Passive acoustic monitoring (vessel- and aircraft-based) was incorporated into these surveys to locate the NPRW as well as to collect data on their spatio-temporal distribution. During these surveys, both gunshots and upcalls were detected and used to locate vocalizing NPRW (Rone et al. 2012). Once located, vessel-based focal follows were conducted to attempt to correlate vocal activity with surface and dive behavior. On multiple occasions, gunshot bouts were directly correlated with the timing of surface and dive patterns. The primary goal of this paper is to discuss the attribution of the gunshot call to NPRW (via focal follows) and the importance of including this call type in acoustic studies of NPRW spatio-temporal distribution. Secondarily, this paper describes the frequency of gunshot production for NPRW and specific call characteristics.

\section{MATERIALS AND METHODS}

\section{Vessels}

Data included in this study were collected over $2 \mathrm{yr}$ from 3 survey vessels (2008: FV 'Ocean Olympic;' 2009: FV 'Aquila' and the NOAA ship 'OSCAR DYSON'). Note that no NPRW were seen or heard in 2007, and none were seen in 2010, therefore no focal follow data were available. The FV 'Ocean Olympic' and the FV 'Aquila' are converted crabbing vessels of similar class and layout, each approximately $51 \mathrm{~m}$ in length. Visual observation platforms were located approximately $6.9 \mathrm{~m}$ above the water line for the FV 'Ocean Olympic' and FV 'Aquila,' and antenna height above the water line was approximately $20 \mathrm{~m}$ for 
both vessels. The NOAA ship 'Oscar Dyson' is a research vessel, approximately $64 \mathrm{~m}$ in length; the visual observation platform was approximately $15 \mathrm{~m}$ above the water line, and antenna height was approximately $25 \mathrm{~m}$ above the water line.

\section{Acoustic data collection}

During all 3 survey cruises, sonobuoys were deployed continuously to acoustically monitor for NPRW calls. A sonobuoy is a free-floating, expendable, shortterm passive acoustic listening device that transmits signals in real time via VHF radio waves to a receiver on a vessel or aircraft (Rone et al. 2012). Sonobuoys used in the current study were AN/SSQ 53E (USS) and $77 \mathrm{C}$ (Sparton). The majority of 53E units were deployed in Directional Frequency Analysis and Recording (DiFAR) mode, and were set to an $8 \mathrm{~h}$ lifespan and $27 \mathrm{~m}$ depth. The DiFAR-only $77 \mathrm{C}$ units were set to an $8 \mathrm{~h}$ lifespan. Because the minimum deployment depth $(61 \mathrm{~m})$ of the $77 \mathrm{C}$ sonobuoys exceeded that of the water depth in the NPRW critical habitat ( $\sim 50 \mathrm{~m})$, modifications were made by tying up sections of the sonobuoy housing to prevent the main wire spool from deploying. These modifications resulted in a deployment depth of approximately $24 \mathrm{~m}$, placing the hydrophone array at approximately $22 \mathrm{~m}$ from the surface (roughly mid-water column). An omnidirectional Morad VHF 156HD antenna was attached to the highest possible location on the vessels. For the FV 'Ocean Olympic' and FV 'Aquila,' this location was on the crow's nest, and for the NOAA ship 'Oscar Dyson,' the antenna was limited to attachment on the flying bridge. Because it was not located in the crow's nest, the line of sight from the antenna to the deployed sonobuoys was occasionally blocked by the ship's infrastructure, resulting in intermittent audio signal as the vessel maneuvered during the focal follows. However, this interruption of signal had a minimal effect on data collection, as multiple buoys were often transmitting simultaneously from a number of locations. In-air reception range was approximately $15-25 \mathrm{~km}$, dependent on sea state conditions, age of the sonobuoy, height of the receiving antenna, and sonobuoy transmission frequency. Average detection range of NPRW calls on the sonobuoy was estimated at $15-25 \mathrm{~km}$ for this study area and time of year, based on localizations of calling animals and their corresponding visual sightings. These ranges are similar to those reported by Rone et al. (2012), and fit within the bounds reported by McDonald \& Moore (2002) and Thode et al.
(2017). In DiFAR mode, the lower limit of the frequency response curve for the $53 \mathrm{E}$ sonobuoys had a flat frequency response $( \pm 3 \mathrm{~dB})$ from 0.6 to $\sim 2 \mathrm{kHz}$, with a low-frequency roll-off of $6 \mathrm{~dB}$ octave $\mathrm{e}^{-1}$ from 10 to $600 \mathrm{~Hz}$ and $18 \mathrm{~dB}$ octave $^{-1}$ below $10 \mathrm{~Hz}$. On the upper end, a sharp roll-off of $35 \mathrm{~dB}_{\text {octave }}{ }^{-1}$ was present. The DiFAR-only $77 \mathrm{C}$ sonobuoys had a similar frequency response with a flat frequency response $( \pm 3 \mathrm{~dB})$ from 0.8 to $2.5 \mathrm{kHz}$, the same low-frequency roll-offs, and a high-frequency roll-off of $25 \mathrm{~dB}$ octave $^{-1}$. In Calibrated Omni mode, the 53E sonobuoy had a flat frequency response from $3.5-25 \mathrm{kHz}$, with a $5 \mathrm{~dB}$ octave $^{-1}$ roll off from $5 \mathrm{~Hz}$ to $3.5 \mathrm{kHz}$, increasing to $9 \mathrm{~dB}$ octave $^{-1}$ below $5 \mathrm{~Hz}$ and above $25 \mathrm{kHz}$. All sonobuoys used in the focal follows were deployed in DiFAR mode; however, occasionally (and outside of the focal follows) sonobuoys were deployed in Calibrated Omni mode to obtain the full frequency bandwidth. Because an MML aerial survey team was also deploying sonobuoys and would often be in the area (Rone et al. 2012), the plane would occasionally deploy a sonobuoy ahead of the vessel that would then be used by the vessel crew once in range.

The signals received by the shipboard antennas were pre-amplified (15 dB; PV160VDA, Advanced Receiver Research), before being sent via cabling to up to 3 G39WSBe WinRadio sonobuoy receivers (frequency range: $136.0-173.5 \mathrm{MHz}$, frequency response: $5 \mathrm{~Hz}-25 \mathrm{kHz}[ \pm 1 \mathrm{~dB}]$; WiNRADiO Communications), then input into either a Creative Soundblaster SB0300 (2008) or a MOTU Ultralite mk3 multichannel (2009) external soundcard. The soundcard digitized the signal at a sampling rate of $48 \mathrm{kHz}$, and was connected to a laptop computer where the recordings were monitored in real-time using ISHMAEL (Mellinger 2001) software. Source levels of received signals were not calculated, as the recording system was not calibrated. Directional bearing information of the calls was obtained using DiFAR demultiplexing software and a custom MATLAB interface (Greeneridge Sciences, Inc., and Whale Acoustics, www.whale acoustics.com). Accuracy of detection localization (estimated from sonobuoy bearing location and actual whale location) was approximately $3-5 \mathrm{~km}$ for distant signals (i.e. tens of kilometers away), to 1$2 \mathrm{~km}$ for nearby signals with good signal to noise ratios, although this varied due to sonobuoy drift, whale movement, etc. A Global Positioning System (GPS) feed into the computer provided the ship's position, updated every minute, as well as the sonobuoy deployment location, and time. A custom tracking and plotting program implemented in MATLAB (CLB) allowed for real-time plotting of the vessel and 
sonobuoy locations, as well as bearing and location coordinates of calling whales. Directional bearing information was calibrated using the ship as a sound source. All data were simultaneously recorded to an external hard drive.

\section{Behavioral data collection}

Focal follows (FFs), in which the behaviors of individual whales were observed and recorded simultaneously with passive acoustic recordings, were conducted from the bridge of the research vessel. Data recorded at the onset of an FF included number of individuals, identities (if known), location, direction and speed of travel (when possible), and behavior. During these FFs, GPS timestamps of vocal activity, surface blows and dive times, and any surface activity were noted to associate behavior with call production. Throughout each FF, distance and bearing estimates of the whale(s) to the ship were obtained when possible using $25 \times$ 'big-eye' binoculars following standard reticle estimation methods from the team of visual observers (e.g. Barlow \& Taylor 2005). Gunshot call times were also noted using the same GPS clock as a means of verifying time synchronization. DiFAR localizations were made on the gunshots detected during the FFs to ensure correct attribution to the visually observed animal and to obtain ranges when possible. Once the visual crew went off effort and began following an animal, their protocol was to not collect re-sight information; as such, there are often only 1 or 2 exact animal locations for an FF. Only single-animal FFs were included in the analyses to ensure correct attribution of the calls to the visually observed individual. Individual NPRW were identified using photo-identification by matching callosity patterns and scars to an MML catalog of known NPRW individuals (A. Kennedy pers. comm.); if no match was made, the individual was added to the catalog. Sex was determined via biopsy sampling (when possible).

\section{Post hoc analyses}

NPRW in the SEBS are sensitive to vessel approach. While typical visual focal follow data include information on surfacings, blows, and dives (e.g. Dolphin 1987, Silber et al. 1988), NPRW display extremely unpredictable surfacing/traveling behavior in the presence of vessels, so it was often difficult for the observers to determine the end of a surfacing se- quence. Therefore, to categorize each inter-blow interval (IBI) as either a surfacing or a dive, a log survivorship analysis was conducted (Fagen \& Young 1978, Martin \& Bateson 1993). This method is based upon the assumption that within-bout and betweenbout intervals result in different rate constants. When plotted on a log survivorship curve, these different rate constants result in 2 distinct near-linear slopes; the point where these 2 slopes join marks the bout criterion interval (BCI), which objectively determines bout intervals. Bout interval durations shorter than the BCI were categorized as surfacings (within-bout intervals), while those with a duration longer than the BCI were categorized as dives (between-bout intervals). However, note that some of the IBIs categorized as dives may in fact be a series of 2 or more shorter IBIs where the surfacings were missed due to the visually cryptic behavior of the focal animal.

Post hoc analyses of gunshots were conducted using the Raven Pro Interactive Sound Analysis Program (Bioacoustics Research Program 2011). Spectrograms were generated (Hanning window, 8192 point FFT, $50 \%$ overlap), and recordings were visually and aurally inspected for the presence of gunshots. Since this provided a coarse time analysis resolution (i.e. $170 \mathrm{~ms}$ ), the focal follow data were rerun (Hanning window, 1024 point FFT, 95\% overlap; $20 \mathrm{~ms}$ time analysis resolution) and the duration of each gunshot call was measured by manually selecting the beginning and ending points. All measurements were made by the same analyst (JLC) for consistency. These points were also used to calculate the inter-call intervals (ICI), which were then used in the same log survivorship analysis described above to categorize each gunshot as being either part of a bout (within-bout) or a single call (between-bout). The number of gunshots, including the total number, the number of single calls, and the number of bouts, were counted for each IBI.

Inter-event interval times were measured from the beginning of each IBI to the first gunshot within that IBI (i.e. blow to gunshot, B-G; Fig. 1) to determine the duration of time between when the whale submerged and when it started calling. Intervals were also measured from the end of the last gunshot within the IBI to the end of that IBI (i.e. gunshot to blow, G-B; Fig. 1) to determine the duration of time between when the whale stopped calling and when it surfaced. This produced a set of intervals annotated with the following categories: surfacing/dive; B-G/G-B; whether the gunshot was part of a bout or a single call; male/ female; individual ID; and time of day. All possible pairwise combinations were analyzed. Finally, all 


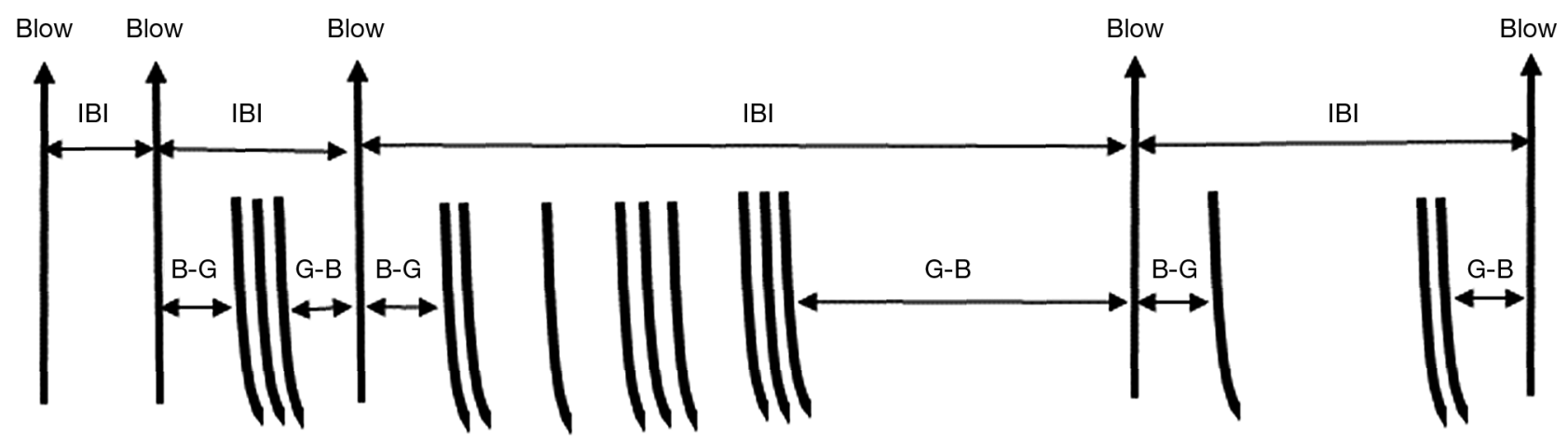

Fig. 1. Schematic of measurements for analysis of gunshot calls and dive pattern behavior of North Pacific right whales Eubalaena japonica. IBI: inter-blow interval, B-G: blow to gunshot, G-B: gunshot to blow

combinations were compared to randomly assigned values within the same time duration range using a Mann-Whitney $U$-test with Monte Carlo simulation (R Programming language).

Because each call was attributed to the focal animal (i.e. limiting to single individuals and obtaining location information from the DIFAR signal), calling rates were obtained for gunshots during the FF times (referred to as FF calling rates). These were calculated by dividing the number of gunshots by the total number of recording minutes analyzed. However, the close proximity of the vessel or skiff to the NPRW during the FFs may have altered their vocal behavior. No upcalls or tonal calls were detected during the FFs, so individual call rates for these call types could not be calculated. To determine the difference in call production rate between gunshots, upcalls (here, inclusive of both upcalls and down-up calls; McDonald \& Moore 2002, Munger et al. 2008), and other tonal calls (downsweeps and moans), a total of over $180 \mathrm{~h}$ of additional recordings were analyzed (referred to as non-FF calling rates). Data analyzed included $8 \mathrm{~d}$ from both years ( 2 d in 2008, 6 d in 2009) in which a visual confirmation of a right whale was made, or every sonobuoy deployed on that day detected at least 1 right whale vocalization, to ensure that the resulting call detection rates were obtained in the presence of NPRW. These data did not include those days in which FF data were analyzed to avoid potential biasing toward gunshot-calling individuals.

\section{RESULTS}

\section{Summary of FFs}

Four individual NPRW were sighted in 2008 and 9 in 2009; none were seen or heard in 2007, and none were seen in 2010. Twenty-three separate FFs were conducted: 4 in 2008 and 19 in 2009. Nine FFs were the result of first visually sighting the animal without acoustic cues, while 14 were the result of locating the animal via calls (both upcalls and gunshots) localized from DiFAR sonobuoys. Sixteen of the 23 FFs contained multiple individuals, reducing the reliability of attributing gunshots to an individual. Therefore, only those FFs that involved a single animal (7 of 23) were included in analyses to ensure correct call attribution. Of these $7 \mathrm{FFs}, 2$ were the result of acoustic localizations, while the other 5 were the result of visual sightings. This subset included data from 2 years (1 FF from 2008, 6 from 2009), 3 months (July to September), and 4 different individuals (2 males, 1 female, 1 unknown; sex determined via biopsy samples; Tables 1 \& 2). All 7 FFs occurred within the NPRW critical habitat; the location of each FF and its corresponding sonobuoy deployment locations are shown in Fig. 2. During the FFs, the distance from the whale to the sonobuoy(s) ranged from 0.6 to $12.1 \mathrm{~km}$ (Table 1). A map showing the boat position and DiFAR localizations from 1 of the FFs (no. 6) is presented in Fig. 3. The sighting history and sex of the 4 individuals included in these 7 FFs are presented in Table 2. Duration of FF events ranged from 7 to $80 \mathrm{~min}$. In most instances, the whale would cease vocalizing and become visually cryptic once the research vessel or skiff (tagging/biopsy platform) came within $500 \mathrm{~m}$, effectively ending the FF.

In all FF events, fin whale Balaenoptera physalus calls were detected (e.g. Watkins et al. 1987). One humpback whale Megaptera novaeangliae was visually sighted in the area during FFs nos. 2 and 3, and was visible with binoculars and/or 25x big-eye binoculars. In both instances, the animal was at least $5 \mathrm{~km}$ away from the NPRW, and no humpback calls were detected during the FF of the NPRW. In all 
Table 1. Summary of the 7 focal follows (FF) of North Pacific right whales Eubalaena japonica included in this study. Whale ID corresponds to the Alaska Fisheries Science Center Marine Mammal Laboratory catalogue number for a photographically identified individual

\begin{tabular}{|c|c|c|c|c|c|c|c|}
\hline \multirow[t]{2}{*}{ FF } & \multirow[t]{2}{*}{ Whale ID } & \multirow{2}{*}{$\begin{array}{c}\text { Date } \\
\text { (mo/d/yr) }\end{array}$} & \multirow{2}{*}{$\begin{array}{l}\text { Start time } \\
\text { (hh:mm:ss) }\end{array}$} & \multirow{2}{*}{$\begin{array}{l}\text { Duration } \\
\text { (hh:mm) }\end{array}$} & \multicolumn{2}{|c|}{-Approx. location -} & \multirow{2}{*}{$\begin{array}{l}\text { Range of whale } \\
\text { to sonobuoy }(\mathrm{km})\end{array}$} \\
\hline & & & & & Latitude $\left({ }^{\circ} \mathrm{N}\right)$ & Longitude $\left({ }^{\circ} \mathrm{W}\right)$ & \\
\hline 1 & NMML 15 & $9 / 03 / 2008$ & $17: 00: 00$ & 00:07 & 56.8410 & 164.7155 & $3.6-12.1$ \\
\hline 2 & NMML 24 & $7 / 31 / 2009$ & $22: 31: 47$ & $00: 11$ & 57.1489 & 163.2286 & $1.3-8.2$ \\
\hline 3 & NMML 24 & $8 / 01 / 2009$ & $10: 26: 49$ & $00: 27$ & 57.2715 & 163.3414 & $5.1-10.7$ \\
\hline 4 & NMML 24 & $8 / 14 / 2009$ & $9: 45: 27$ & $00: 28$ & 57.3733 & 163.7272 & $3.1-8.4$ \\
\hline 5 & NMML 24 & $8 / 22 / 2009$ & $18: 00: 08$ & $00: 41$ & 57.7240 & 164.8732 & $1.3-7.1$ \\
\hline 6 & NMML 87 & $8 / 23 / 2009$ & $14: 58: 51$ & $01: 20$ & 57.1946 & 164.0870 & $0.6-4.8$ \\
\hline 7 & NMML 85 & $8 / 23 / 2009$ & $18: 10: 03$ & $01: 14$ & 57.1397 & 163.8923 & $6.0-8.4$ \\
\hline
\end{tabular}

Table 2. North Pacific right whale Eubalaena japonica ID number, sex, sighting history, average number of gunshot (GS) calls bout ${ }^{-1}$, mean (with SD in parentheses) inter-call interval (ICI) in seconds for GS in bouts, and the ratio of GS produced in a bout (GS bout $)$ vs. single GS (GS single $)$ for each individual North Pacific right whale in the focal follows. Whale ID corresponds to the Alaska Fisheries Science Center Marine Mammal Laboratory catalogue number. Sighting history: years sighted

\begin{tabular}{|c|c|c|c|c|c|}
\hline Whale ID & Sex & $\begin{array}{l}\text { Sighting } \\
\text { history }\end{array}$ & $\begin{array}{l}\text { Mean no. } \\
\text { GS bout }^{-1}\end{array}$ & $\begin{array}{l}\text { Mean (SD) } \\
\text { bout ICI (s) }\end{array}$ & $\begin{array}{l}\text { GS }_{\text {bout }} \\
\text { GS }_{\text {single }}\end{array}$ \\
\hline NMML 24 & M & 2004,2009 & 7.04 & $2.4(0.45)$ & $14.4: 1$ \\
\hline NMML 85 & M & 2009, 2011 & $8.2^{\mathrm{a}}$ & $3.5(1.2)$ & $1.9: 1$ \\
\hline NMML 15 & Unk & $\begin{array}{l}2000,2004 \\
2008,2009\end{array}$ & 17.0 & $3.6(0.8)$ & $51: 0$ \\
\hline NMML 87 & F & 2009 & 2.25 & $4.3(1.2)$ & $0.3: 1$ \\
\hline
\end{tabular}

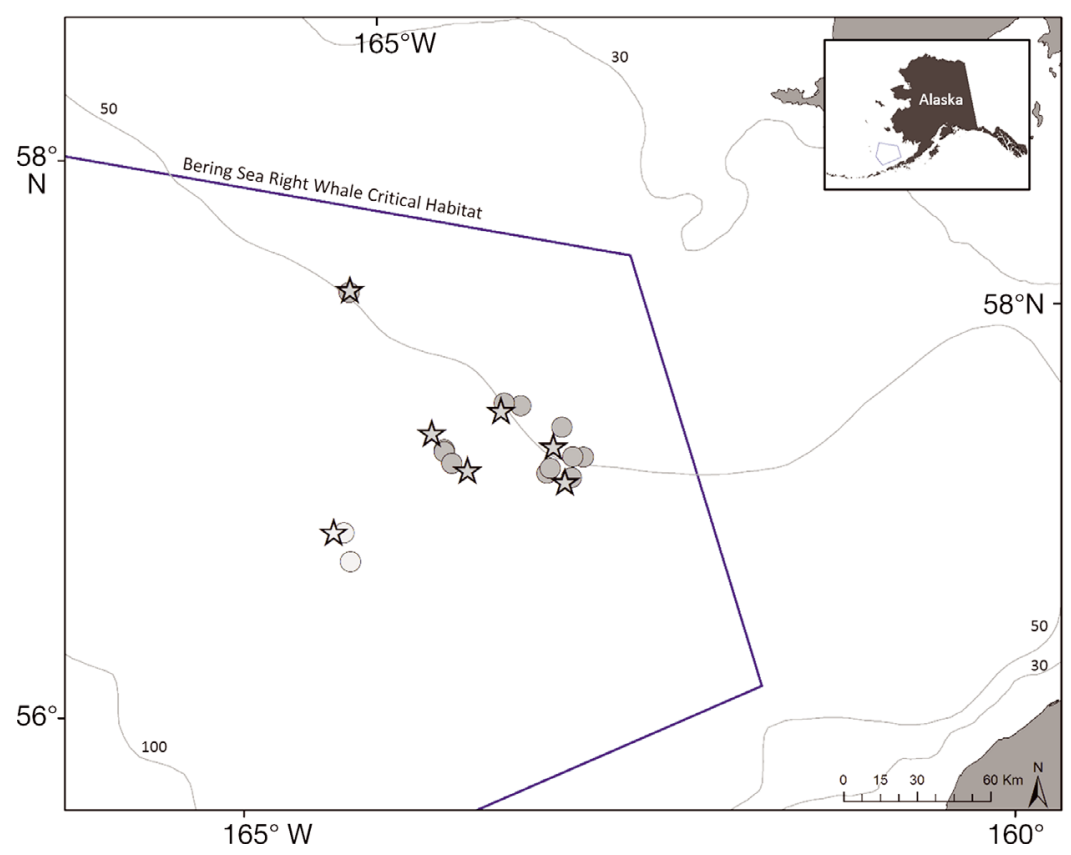

Fig. 2. Study area in the southeastern Bering Sea, Alaska, USA. Circles: sonobuoys included in focal follows (FFs) of North Pacific right whales Eubalaena japonica. Stars: approximate location of FFs. Shading of symbols: light gray $=$ 2008, dark gray $=2009$. Pentagon: federally designated North Pacific right whale critical habitat other FFs, no humpback whales were visible in the area. During FFs nos. 1 and 6, 2 right whales were calling, although only 1 whale was visible. In addition to producing different DiFAR bearing localizations, gunshots from these 2 callers were easily distinguished based on the lower amplitude and propagation distortion of the calls of the distant whale. Only those gunshots from the focal animal were included in analyses.

\section{NPRW gunshot parameters}

Gunshots were detected in bouts and as single calls. Average gunshot frequency range for all gunshots was $100-2000 \mathrm{~Hz}$ (range $=50 \mathrm{~Hz}-5.5 \mathrm{kHz}$; Fig. 4). Average duration was $0.27 \mathrm{~s}$ (range $=0.16-0.61 \mathrm{~s}$ when the whale was estimated to be within $3 \mathrm{~km}$ of receiver, $\mathrm{n}=251$ ), but could be as long as $1.25 \mathrm{~s}$ for distant signals. The BCI, calculated from the log survivorship analysis, was $6 \mathrm{~s}$ (Fig. 5A). Thus, any gunshots produced within $6 \mathrm{~s}$ of each other were considered part of the same bout. Using this criterion, there were 56 instances of gunshot bouts and 139 single calls in the FFs. The overall average number of gunshots bout $^{-1}$ was 7.9 (range $=2-26, \mathrm{SD}=$ $5.0)$, and the average ICI for gunshots in bouts was $3.0 \mathrm{~s}$ (range $=1.5-6, \mathrm{SD}=$ $0.9)$. Interestingly, while all other individuals produced multiple bouts with numerous (i.e. >10) calls bout ${ }^{-1}$, NMML 87 (female) produced only 2 to 4 gun- 


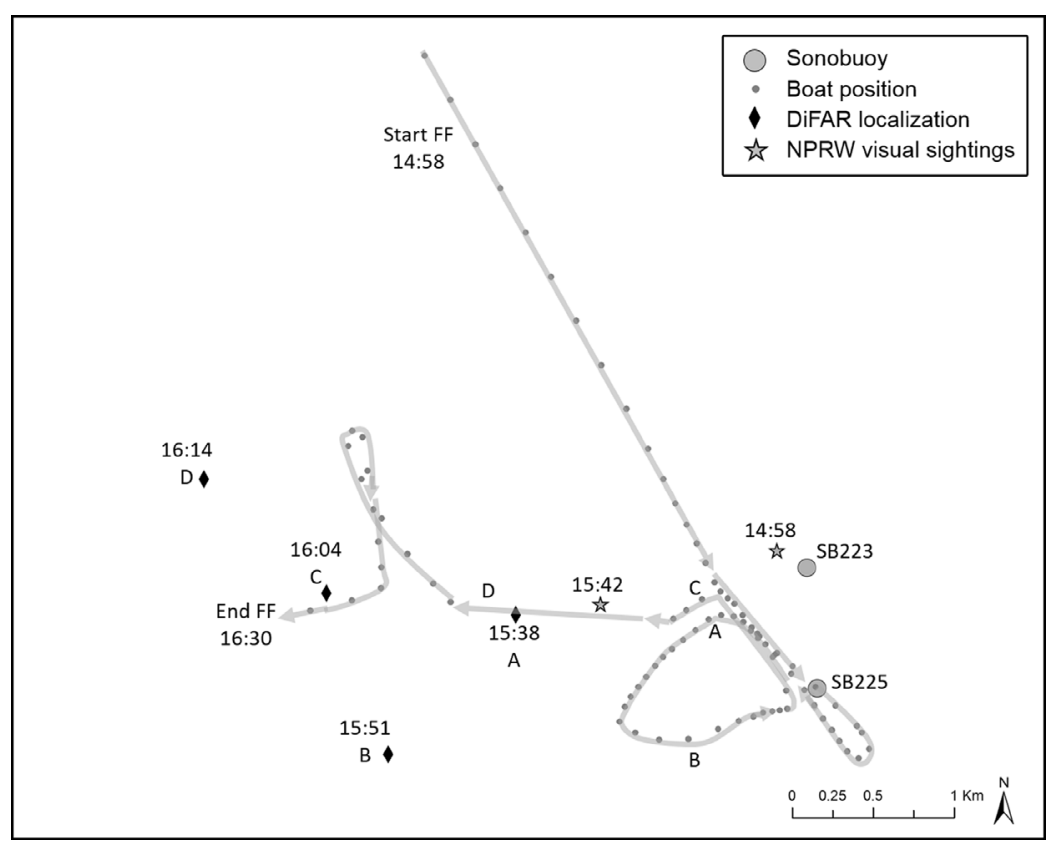

Fig. 3. Details of North Pacific right whale (NPRW) Eubalaena japonica focal follow (FF) no. 6. Gray circles: sonobuoy locations. Note: SB223 was deployed from the aerial plane ahead of the vessel. Small dots: boat position (updated every minute). Gray stars: visual sightings of the focal animal during FF no. 6. Black diamonds: localizations of the calling focal animal (DiFAR: Directional Frequency Analysis and Recording). Letters indicate boat location at time of localization or sighting of focal animal. Light gray arrows superimposed over boat positions illustrate direction of travel. Start of the FF is indicated at the top of the map; from there, we worked south and deployed SB225, then followed the focal animal around the area

shots bout ${ }^{-1}$ (Table 2). Although her ICI of gunshots within bouts was similar to the other individuals, the majority of her calls were single calls. Furthermore, the gunshots in her bouts had irregular timing, unlike the evenly patterned gunshot bouts of the other individuals. No upcalls or tonal calls were detected in the 7 FFs used in these analyses.

\section{Timing of NPRW gunshots with surface and dive behavior}

The log survivorship analysis of IBIs resulted in a plot with a noticeable shift in slope at $40 \mathrm{~s}$ (Fig. 5B). Based on this, the BCI was set at $40 \mathrm{~s}$; those IBIs shorter than $40 \mathrm{~s}$ were classified as surfacings, while those longer than $40 \mathrm{~s}$ were considered dives. This is slightly higher than the NARW BCI value of $27 \mathrm{~s}$ reported by Winn et al. (1995). The mean \pm SD IBI for surfacings was $23.5 \pm 7.3 \mathrm{~s}(\mathrm{n}=109$, range $=9-40 \mathrm{~s})$. The mean IBI for dives was $204.7 \pm 157.1 \mathrm{~s}(\mathrm{n}=64$, range $=41-726 \mathrm{~s}$ ).
Gunshots were associated with both surfacing sequences as well as dives. In both cases, the majority occurred closer to the end of the sequence than to the beginning (Fig. 6). For surfacing sequences $(\mathrm{n}=25$, Fig. $6 \mathrm{~A})$, the time from blow to first gunshot (B-G; Fig. 1) ranged from 3 to $27 \mathrm{~s}$ (mode $=13 \mathrm{~s}$, mean $=11.5 \mathrm{~s}$, median $=11 \mathrm{~s}$ ), while the time from last gunshot to next blow (G-B; Fig. 1) ranged from 2 to $27 \mathrm{~s}$ $($ mode $=7 \mathrm{~s}$, mean $=8.7 \mathrm{~s}$, median $=$ $7 \mathrm{~s})$. More variability was seen with dive sequences ( $\mathrm{n}=42$, Fig. $6 \mathrm{~B})$; the BG time (Fig. 1) ranged from 2 to $146 \mathrm{~s}$ $($ mode $=22 \mathrm{~s}$, mean $=52.1 \mathrm{~s}$, median $=$ $40.5 \mathrm{~s}$ ), while G-B time (Fig. 1) ranged from 2 to $331 \mathrm{~s}$ (mode $=5 \mathrm{~s}$, mean $=$ $48.1 \mathrm{~s}$, median $=21.5 \mathrm{~s}$ ). However, these values are still significantly different than values expected due to random chance (Mann-Whitney $U$ test; $\mathrm{p}=0.0002$ for surfacings, and $\mathrm{p}=$ 0.01 for dives). Further categorization of the gunshots into bouts vs. single calls revealed no significant difference in call vs. blow timing. Differences among individuals, between sexes, and between morning/evening were investigated, but sample sizes were too small for meaningful comparisons.

Gunshots were more common during dives than surfacing sequences. Of the 109 surfacing sequence IBIs, $77 \%$ had no gunshots, $16 \%$ had only single gunshots, and only $7 \%$ had gunshot bouts. In comparison, out of 64 dives, $34 \%$ had no gunshots, $37 \%$ had only single gunshots, and $28 \%$ had gunshot bouts. An average of 3.2 gunshots were produced per surfacing IBI, compared to 12.1 gunshots per dive IBI. Although call rates for each IBI showed considerable variation, the average call rate for surfacings was half that of the dives ( 79.8 vs. 155.9 calls $^{-1}$ ).

\section{NPRW calling rates}

Gunshot calling rates for the FFs are presented in Table 3 . The average calling rate for the 5 male FFs was 156.1 calls h$^{-1}$; the rate for the 1 female FF was roughly a third that of the males, at 54.1 calls $^{-1}$. However, because there was only 1 known female included in the analysis (FF no. 6), this number should not be interpreted as a true representation of female 


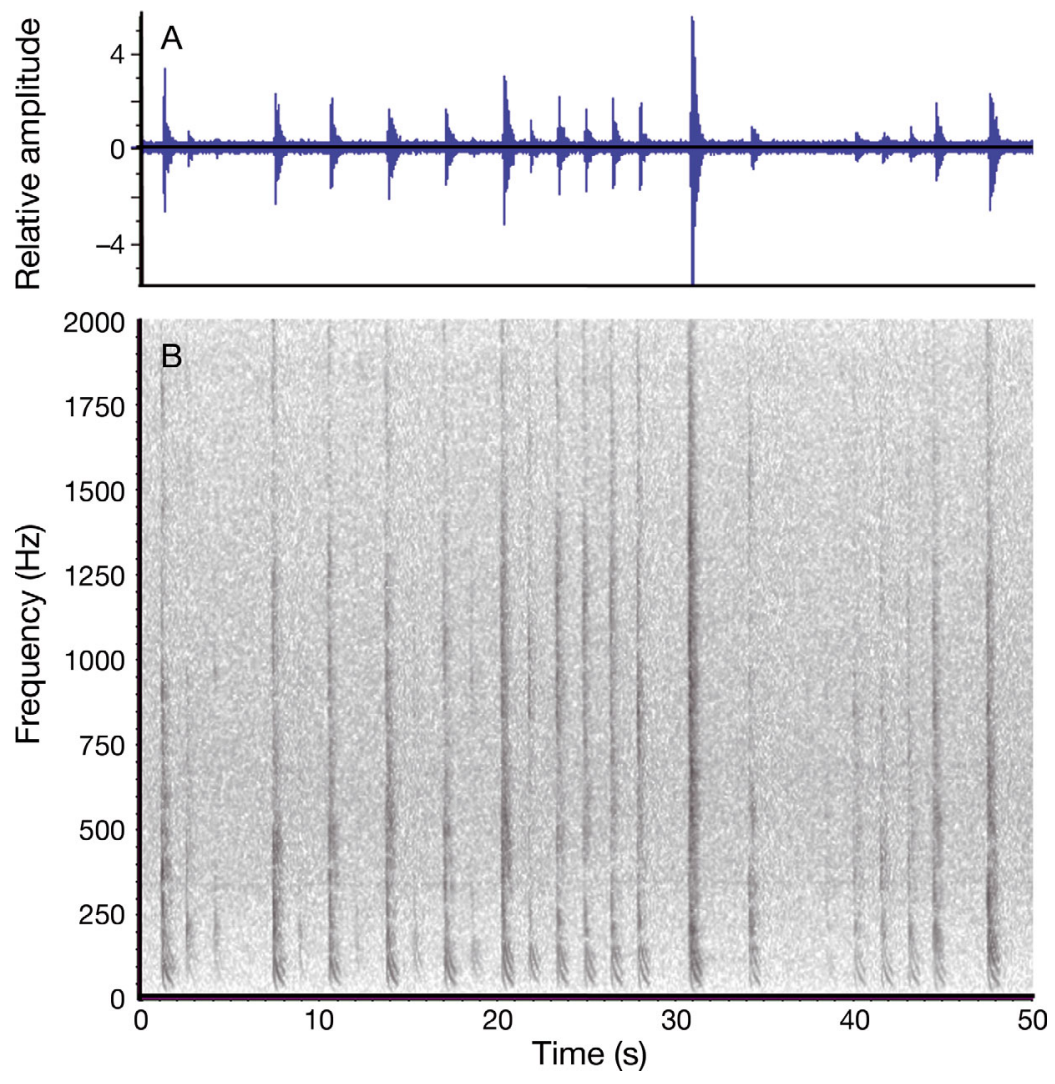

Fig. 4. Example of a North Pacific right whale Eubalaena japonica gunshot bout. (A) Waveform of gunshots. (B) Spectrogram of gunshots showing both the call characteristics as well as the frequency of call production (1024-point fast Fourier transform [FFT], 95\% overlap, Hamming window with 500 points zero padding)

gunshot calling rates. The gunshot calling rate averaged over all individuals was 133.0 calls $^{-1}$ (range $=$ 38.9-425.0 calls $\mathrm{h}^{-1}$ ). Removal of the 2 brief FFs (FF nos. 1 and 2) resulted in a similar calling rate (149.2 calls $\mathrm{h}^{-1}$ ). No upcalls were detected during the FFs.
Non-FF calling rates obtained from the additional $180 \mathrm{~h}$ of data (Table 4 ) were orders of magnitude higher for gunshots than upcalls or tonal calls. Gunshots were detected on average over 53 times more often than upcalls, and over 200 times more frequently than other tonal calls. The overall average non-FF gunshot calling rate was 228.3 calls $^{-1}$ (range $=$ 5.3-835.7, SD = 204.9); the highest measured was from one $10 \mathrm{~min}$ file containing 253 gunshots (4 September 2008, 07:10 h Alaska Daylight Time). The overall calling rate was 4.3 calls $^{-1}$ (range $=0-36.0, \mathrm{SD}=$ 8.1) for upcalls and 1.12 calls $h^{-1}$ (range $=0-4.3, \mathrm{SD}=1.3$ ) for tonal calls.

\section{DISCUSSION}

\section{Attribution of gunshots to NPRW}

The results presented in this study definitively attribute gunshots to NPRW. Although DiFAR localizations on gunshots resulted in visual sightings of NPRW, and those localized during FFs corresponded closely to the location of the focal animal, the most incontrovertible evidence is the correlation of the gunshot call timing with the surfacing behavior. Gunshot production ceased seconds before a blow, only to resume shortly after the animal submerged.
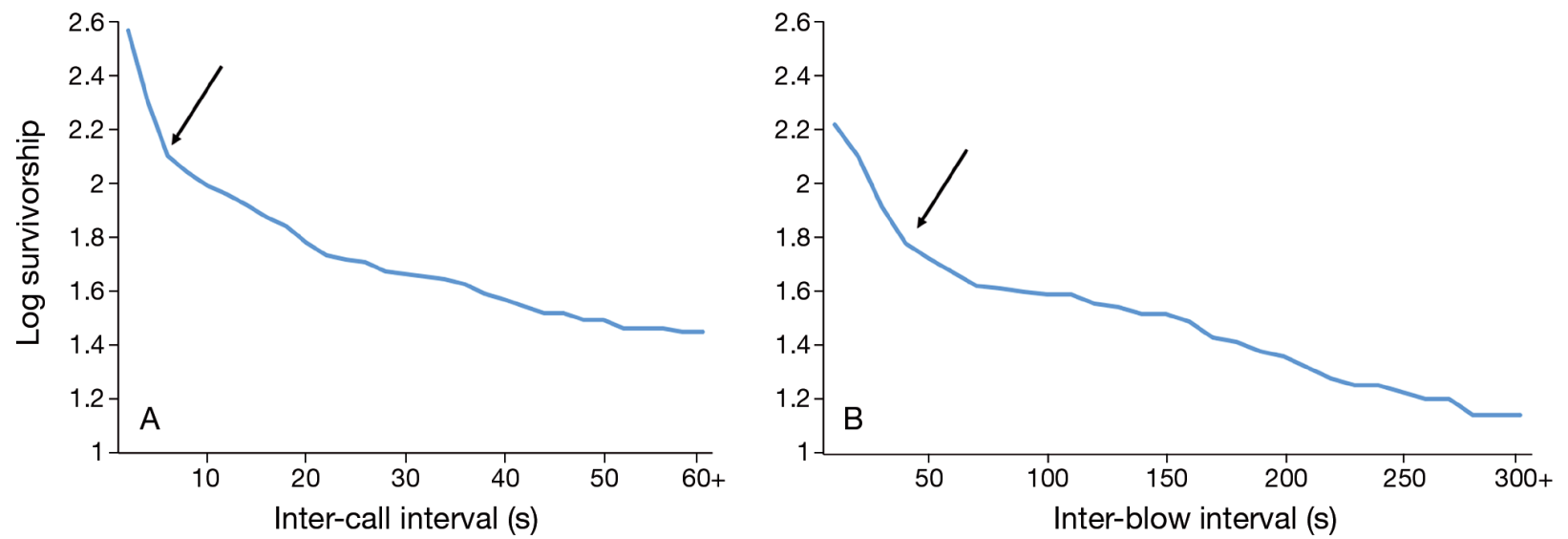

Fig. 5. Log-survivorship plots of North Pacific right whale Eubalaena japonica (A) gunshot inter-call intervals, and (B) interblow intervals. The arrows show the changes in slope at $6 \mathrm{~s} \mathrm{(A)} \mathrm{and} 40 \mathrm{~s}$ (B) which were used to define the bout criterion intervals for gunshot bouts and dive intervals. Data truncated at $60 \mathrm{~s}$ (A) and $300 \mathrm{~s}$ (B) to more clearly show the break in slope 


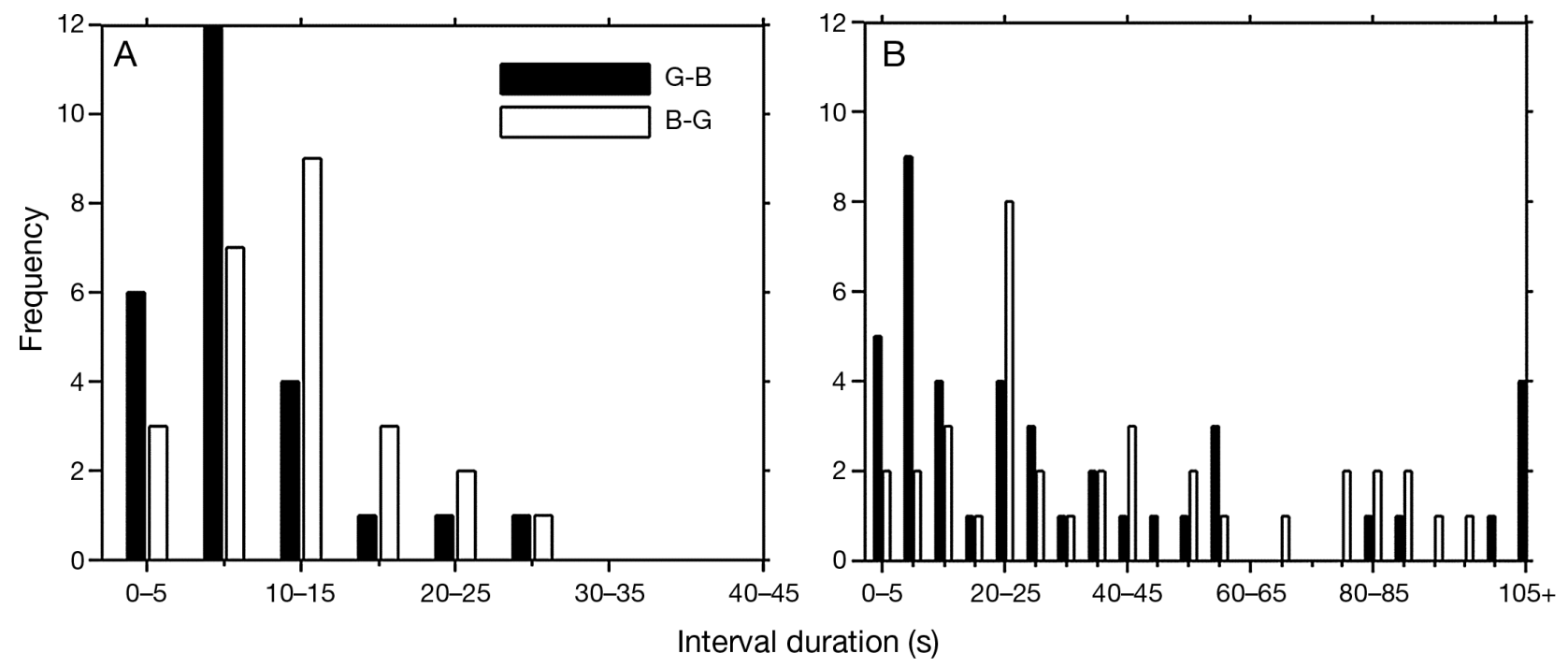

Fig. 6. Frequency distribution of inter-event intervals among all North Pacific right whale Eubalaena japonica individuals for (A) surfacings and (B) dives. Solid black: gunshot to blow intervals (G-B, see Fig. 1); white: blow to gunshot intervals (B-G, see Fig. 1)

Table 3. Gunshot (GS) calling rates for each North Pacific right whale Eubalaena japonica focal follow (FF), averaged over all FFs, and by sex

\begin{tabular}{|lccrrr|}
\hline $\begin{array}{l}\text { Group- } \\
\text { ing }\end{array}$ & $\begin{array}{c}\text { Whale } \\
\text { ID }\end{array}$ & Sex & $\begin{array}{c}\text { No. of GS } \\
\text { detected }\end{array}$ & $\begin{array}{c}\text { Total } \\
\text { hours }\end{array}$ & $\begin{array}{c}\text { Call rate } \\
\text { (GS h }{ }^{-1} \text { ) }\end{array}$ \\
\hline FF 1 & NMML 15 & Unk & 51 & 0.12 & 425.00 \\
FF 2 & NMML 24 & M & 7 & 0.18 & 38.89 \\
FF 3 & NMML 24 & M & 35 & 0.46 & 76.09 \\
FF 4 & NMML 24 & M & 167 & 0.47 & 355.32 \\
FF 5 & NMML 24 & M & 72 & 0.69 & 104.35 \\
FF 6 & NMML 87 & F & 72 & 1.33 & 54.14 \\
FF 7 & NMML 85 & M & 192 & 1.23 & 156.10 \\
Overall & & & 596 & 4.48 & 133.04 \\
Known male & & 473 & 3.03 & 156.11 \\
Known female & & 72 & 1.33 & 54.14 \\
\hline
\end{tabular}

This is not the first study to visually locate NPRW by first localizing on the gunshot. During aerial surveys for NPRW in 2009, Rone et al. (2012) were able to localize on, and subsequently visually sight, NPRW using both gunshots and upcalls. Five of their 22 visual sightings were first located by acoustic detections, and 2 of those 5 were in a sea state of Beaufort 7, conditions that would be nearly impossible to detect a whale using visual methods alone. However, ours is the first study to correlate the timing of NPRW surface and dive sequences with gunshots, conclusively attributing the gunshot call to this species.

During all FFs, no surface active behavior was seen, confirming that this call type is produced internally and not by surface impact (i.e. flipper/tail slapping or breaching). This is supported by Rone et al.

Table 4. Summary of North Pacific right whale Eubalaena japonica non-focal follow data analyzed, including total number of calls detected, daily average calling rate with range in parentheses (calls $\mathrm{h}^{-1}$ ) for gunshots, upcalls, and tonal calls

\begin{tabular}{|c|c|c|c|c|c|c|c|}
\hline \multirow{2}{*}{$\begin{array}{l}\text { Date } \\
(\mathrm{mo} / \mathrm{d} / \mathrm{yr})\end{array}$} & \multirow{2}{*}{$\begin{array}{l}\text { No. hours } \\
\text { analyzed }\end{array}$} & \multicolumn{2}{|r|}{ - Gunshots } & \multicolumn{2}{|c|}{$\longrightarrow$ Upcalls } & \multicolumn{2}{|c|}{ Tonal calls } \\
\hline & & Total no. & $\begin{array}{l}\text { Mean call rate } \\
\text { (range) }\end{array}$ & Total no. & $\begin{array}{l}\text { Mean call rate } \\
\text { (range) }\end{array}$ & Total no. & $\begin{array}{c}\text { Mean call rate } \\
\text { (range) }\end{array}$ \\
\hline $8 / 8 / 08$ & 22.2 & 1145 & $51.6(10.37-90.75)$ & 264 & $11.9(0.27-35.97)$ & 29 & $1.3(0-3.79)$ \\
\hline $9 / 4 / 08$ & 23.7 & 11873 & $500.9(195.3-835.7)$ & 59 & $2.5(0.13-6.08)$ & 13 & $0.55(0-1.03)$ \\
\hline $7 / 24 / 09$ & 23.3 & 3372 & $144.7(12.49-225.55)$ & 83 & $3.6(0.41-8.96)$ & 38 & $1.63(0.21-3.68)$ \\
\hline $7 / 25 / 09$ & 23.8 & 2739 & $115.1(5.25-175.6)$ & 33 & $1.4(0.13-2.38)$ & 35 & $1.47(0.63-3.13)$ \\
\hline 7/26/09 & 22.6 & 5509 & $243.76(54.38-304.25)$ & 59 & $2.6(0.78-3.25)$ & 50 & $2.21(0-4.25)$ \\
\hline $7 / 27 / 09$ & 22.8 & 9271 & $406.6(106.5-662.82)$ & 47 & $2.1(0.00-3.53)$ & 11 & $0.48(0-0.85)$ \\
\hline 7/28/09 & 22.4 & 2387 & $106.6(37.43-214.47)$ & 22 & $0.98(0.13-1.15)$ & 7 & $0.31(0-0.47)$ \\
\hline 8/15/09 & 21.5 & 5338 & $248.3(62.1-464.91)$ & 214 & $9.95(1.4-21.96)$ & 22 & $1.02(0-1.91)$ \\
\hline Total & 182.3 & 41634 & 228.38 & 781 & 4.28 & 205 & 1.12 \\
\hline
\end{tabular}


(2012), who also reported no surface activity in the presence of NPRW producing gunshots. These results also concur with those reported from the NARW and SRW populations (Clark 1983, Parks et al. 2005).

\section{Other sources of impulsive sounds in the Bering Sea}

Impulsive sounds have been reported in the presence of other species/sound sources. These sounds vary in their degree of similarity to the NPRW gunshot, and their sources vary in spatio-temporal overlap with NPRW. Bowhead whales Balaena mysticetus are the only other Bering Sea species known to produce gunshots (Würsig \& Clark 1993); however, they are not present in the SEBS during July to September. Other species with impulsive sounds, i.e. North Pacific walrus Odobenus rosmarus and gray whale Eschrichtius robustus, produce knocks that are easily distinguished from gunshots (e.g. Stirling et al. 1987, Hannay et al. 2013, Youngson \& Darling 2016). Furthermore, like bowhead whales, these species are not typically present in the study area during the July to September time period (Burns 1970, Fay 1982), and were not sighted during our surveys.

Fin whales can also produce sharp, impulsive, broadband sounds. These sounds coincide with feeding behaviors (Watkins 1981, Brodie 1993) and are thought to stun and retain prey within their throat pouch (Brodie 1993). Although these sounds are spectrographically similar to gunshots, it is unlikely that they are the source of the impulsive sounds recorded in our dataset. Localizations of the gunshots placed the source at the location of the right whale, and at a different location than both the $20 \mathrm{~Hz}$ fin calls and the visually sighted fin whales. Furthermore, the frequency of gunshot production rules out fin whales as the source of production. Gunshots were reported being produced at rates of up to 425 calls $\mathrm{h}^{-1}$, a rate too high to be limited to surface lunge feeding behaviors.

Sounds from breaches and fluke/flipper slapping are commonly reported for humpback whales (Thompson et al. 1986). Although these sounds have similarities to gunshots, in our study, humpback whales were only sighted in the area during 2 of the 7 FFs; in both instances, they were over $5 \mathrm{~km}$ from the focal animal, and no surface activity was observed. In addition, no typical humpback whale calls were detected during any FF. Gunshots have not been reported in the extensive literature for humpback whales (e.g. Payne \& McVay 1971, Thompson et al. 1986, Cerchio \& Dahlheim 2001, Dunlop et al. 2007, 2008, Stimpert et al. 2011); however, both NARW and SRW are known to produce this call type. Given the similarities between right whale upcalls and some humpback vocalizations, the inclusion of the gunshot in the NPRW vocal repertoire will aid in correctly attributing the sometimes ambiguous upcalls and distinguishing these vocally similar species.

Seismic airguns produce loud, impulsive, broadband signals that may look and sound spectrographically similar to gunshots. However, airgun pulses are produced at very patterned and regular intervals for very long periods of time. The gunshots detected here are too irregular to be airgun pulses. Additionally, no seismic activity was occurring in the area at the time of the survey.

Another anthropogenic source of gunshot-like sounds are 'seal bomb' explosions (i.e. underwater firecrackers used to deter marine mammals from fishing gear; Awbrey \& Thomas 1984). The use of seal bombs in fisheries activities is common in other areas. For example, Baumann-Pickering et al. (2013) reported high numbers of explosions (a maximum of $500 \mathrm{~h}^{-1}$ ) in southern California (USA). These high numbers of explosions likely came from numerous fishing vessels in the area at once. The use of seal bombs is no longer common in the Bering Sea, however, after strict regulations were imposed in 2011. There was only 1 documented case of seal bomb use in the Bering Sea from 2008 through 2009 (E. Chilton pers. comm.). Although a lack of documentation does not imply lack of use, the extremely low documentation rate makes it unlikely that seal bombs are used with great enough frequency to be confused with gunshots in this area (e.g. maximum calling rates of up to 835 gunshots in one 10 min file). Furthermore, we observed no fisheries activities in the area during the study period.

\section{Comparison of gunshot characteristics among right whale species}

While all gunshots are loud, broadband, impulsive signals, those recorded from NPRW are slightly different than those of the NARW and SRW. It is important to note that propagation effects will distort the signal at distances greater than several water depths, typically interpreted as more than 10 times the water depth (Medwin \& Clay 1998). For the study area, this means all gunshot calls recorded at greater than 500-700 $\mathrm{m}$ will show modal dispersal, which is the majority of the FF data set. All measurements are presented with these caveats. The NPRW gunshot is slightly longer in duration than its NARW and SRW 
counterparts. Although the average duration (0.27 s) is similar to those reported for NARW and SRW (0.02$0.34 \mathrm{~s}$ and 0.1-0.4 s, respectively; Clark 1983, Parks et al. 2005, Trygonis et al. 2013, Webster et al. 2016), the range of durations was larger (0.16-1.25 s). NPRW gunshots appear to have a smaller frequency band, with most energy from 100 to $2000 \mathrm{~Hz}$ (range $=50 \mathrm{~Hz}-$ $5.5 \mathrm{kHz}$ ), even for close range (within $3 \mathrm{~km}$ ) signals. Although this is similar to the frequency range reported by Clark (1983) for the SRW ('major energy 50-1000 Hz,' C. Clark pers. comm.), Webster et al. (2016, p. 236) found most of their recorded gunshots '... exceeded the bandwidth of the recording spectrum $(24 \mathrm{kHz})$...'. Parks et al. (2005) also reported a recorder-limited frequency range for their NARW gunshots of $20 \mathrm{~Hz}-20 \mathrm{kHz}$, similar to that reported by Trygonis et al. (2013) for NARW.

However, given the vastly different oceanographic and bathymetric features of the different geographic regions these species inhabit, and differences in recording system placement and parameters, such comparisons of gunshot characteristics may not be meaningful, as any differences could be an artifact of propagation effects or recording system limitations and not representative of true differences in sound production. For example, the longer durations seen in the shallower environments (e.g. $<50 \mathrm{~m}, 50-70 \mathrm{~m}$; Clark 1983 and this study, respectively) could be the result of combined multipath arrivals. The higher frequency ranges seen in a few studies (i.e. Parks et al. 2005, Trygonis et al. 2013, Webster et al. 2016), likewise, could be explained by the closer proximity of their hydrophones (1.5-4 m depth) to the gunshots made at or near the surface, as well as the short distance (often $<100 \mathrm{~m}$ ) from the whale to the hydrophone, which limits the attenuation of higher frequencies (Hamilton 1980). Furthermore, the absence of higher frequencies in the Clark (1983) study, although conducted in shallow water and with the whales in close proximity to the hydrophones, was due to recording system limitations. However, further recordings of NPRW gunshot calls in a variety of locations and environments, using recording systems with higher frequency limits and sensors placed closer to the surface, would help determine if a real difference exists between this and the other 2 right whale species.

Although the characteristics of individual gunshots may be propagation dependent, their timing is not; differences in gunshot timing can therefore be compared among right whale species. The most striking difference seen was in the timing of the gunshots relative to surfacings and dives. In this study, gunshots were more common during dives than surfacing sequences for NPRW. Conversely, NARW gunshots were associated more frequently with surfacing sequences (Parks et al. 2005). While this might be an artifact of the difference in the definition of surfacing and dive sequences between the 2 studies (i.e. we used the BCI to differentiate between the 2, while Parks et al. 2005 used visual observation), it is important to note that the NARW were observed to be at the surface (and not taking a breath) when the most gunshots were detected (Parks et al. 2005). In this study, NPRW were not observed lingering on the surface between breaths, although this may be a result of their erratic behavior in the presence of vessels. Another difference in timing between these 2 species is that while our results show gunshot production skewed toward the end of a dive sequence (i.e. right before surfacing), Parks et al. (2005) found a few gunshots occurring immediately before surfacing or immediately after diving. Note that Parks et al. (2005) defined the surfacing interval as including all surfacings from the first breath after a dive until the subsequent dive. We considered each time between breaths at the surface as a surfacing interval, and the set of surfacing intervals to be the surfacing sequence.

Interestingly, the $\mathrm{BCI}$ for determining bouts of gunshots was $6 \mathrm{~s}$. This is considerably lower than values reported for NARW (Parks \& Tyack 2005, Parks et al. 2011, 2012). Parks et al. (2011) reported a BCI of $130 \mathrm{~s}$ for a tagged whale, while an earlier study by Parks \& Tyack (2005) calculated a BCI of $90 \mathrm{~s}$ for surface active groups (SAGs). Note that those BCIs included all call types, while the BCI here is specific to gunshots. Parks et al. (2012) calculated a BCI specific to gunshot calls for NARW of $30 \mathrm{~min}$, considerably longer than the $6 \mathrm{~s}$ BCI reported here; however, their BCI was calculated from the gunshots produced by up to 7 whales, while ours was based on single individuals.

\section{Calling rates}

Because every call was documented during the FFs, and only single animal FFs were measured, calling rates for individual whales could be determined. The calling rate of gunshots reported in our study $\left(\right.$ Table 5, mean $=133.0$ calls $\mathrm{h}^{-1}$, range $=$ 38.9-425.0 calls $\mathrm{h}^{-1}$ ) is similar to that reported by Rone et al. (2012), when limiting their results to just those recording sessions where right whales were

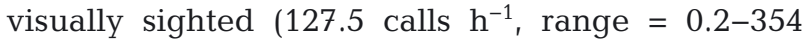
calls $\mathrm{h}^{-1}$ ). Although the data of Rone et al. (2012) 
Table 5. Comparison of some reported average gunshot calling rates (calls $\mathrm{h}^{-1}$ ) across all right whale (Eubalaena spp.) species. Values are reported as either mean (range), mean $\pm \mathrm{SD}$, or range of means. NPRW (NARW): North Pacific (Atlantic) right whale, SRW: southern right whale, SEBS: southeastern Bering Sea, FF: focal follow

\begin{tabular}{|c|c|c|c|c|c|}
\hline Population & Location & Mean call rate (range) & No. of callers & Reference & Notes \\
\hline \multirow[t]{4}{*}{ NPRW } & SEBS & $133.04(38.89-425.0)$ & 1 & Current study & FF data \\
\hline & SEBS & $228.28(5.25-835.7)$ & Unknown & Current study & Non-FF data \\
\hline & SEBS & $69(0.18-354)$ & Unknown & Rone et al. (2012) & $\begin{array}{l}\text { Data collected in same } \\
\text { years and location as } \\
\text { current study }\end{array}$ \\
\hline & Several & 0 & 1 & Matthews et al. (2001) & $\begin{array}{l}\text { Single animals did not } \\
\text { vocalize }\end{array}$ \\
\hline \multirow[t]{5}{*}{ NARW } & Several & $0.6-40.8$ & $2-5$ & Matthews et al. (2001) & \\
\hline & Several & $0.6-262.2$ & $10+$ & Matthews et al. (2001) & \\
\hline & Bay of Fundy & $110.9 \pm 158.3$ & Up to 2 & Parks et al. (2012) & 2004 data \\
\hline & Bay of Fundy & $74.9 \pm 111.4$ & Up to 7 & Parks et al. (2012) & 2005 data \\
\hline & Southeastern US & 27.9 (range unknown) & $3-7$ & Trygonis et al. (2013) & \\
\hline \multirow[t]{2}{*}{ SRW } & Argentina & $0-6.5$ & Unknown & Clark (1983) & Values include 'under- \\
\hline & Auckland Islands & 2.4 (range unknown) & Unknown & Webster et al. (2016) & $\begin{array}{l}\text { water slaps' and other } \\
\text { surface-activity slaps }\end{array}$ \\
\hline
\end{tabular}

were obtained in the same year (2009) and the same region, there were only 2 days (1 and 22 August 2009) where acoustic data collection overlapped between the 2 studies. A few NARW studies present gunshot calling rates for solitary individuals. Parks et al. (2005) reported that lone males produce a large number of gunshots in comparison with gunshots produced in SAGs. Single males were also the most prolific gunshot producers for SRW (Clark 1983). Parks et al. (2011) were able to obtain a gunshot calling rate (from acoustic tag recordings) of 24.5 calls $\mathrm{h}^{-1}$. It should be noted that only one of their 46 tagged NARW (an adult male) produced gunshots. Although this individual produced 189 gunshots over the $7.7 \mathrm{~h}$ tag duration, 187 of those were produced in a single bout lasting $58 \mathrm{~min}$ (193 calls $\mathrm{h}^{-1}$ ), closer to that seen for NPRW in this study (S. Parks pers. comm.). Parks et al. (2012) also reported a similar average rate in 2005 of 110.9 calls $\mathrm{h}^{-1}$ for groups of up to 2 NARW.

For a more complete comparison to other populations in the literature, and for comparison between call types, additional non-FF calling rates (hereafter 'calling rates') were obtained. Although the number of callers was unknown, the low visual sighting rate despite excellent conditions makes it unlikely that more than a few callers were within detection range at any given time. There are likely seasonal biases to the values reported here; however, given the extreme paucity of data on NPRW call production in other locations, a comprehensive comparison is not possible at this time. These numbers are presented to serve as a baseline for future comparisons.
The non-FF NPRW gunshot calling rates obtained in the current study (i.e. mean $=228$ calls $^{-1}$; range $=$ 5-835 calls $\mathrm{h}^{-1}$ ) are higher than those reported for both the NARW and SRW (Table 5). For NARW, the maximum average gunshot calling rate reported by Matthews et al. (2001) was 40 calls h$^{-1}$ for groups of 2 to 5 whales and 262 calls $\mathrm{h}^{-1}$ for groups of 10 or more whales; however, both are within the range of gunshot rates seen for single NPRW in this study. The maximum average gunshot rate of 24 calls $\mathrm{h}^{-1}$ reported by Matthews et al. (2014) for NARW during the night unfortunately cannot be used for comparison, as that analysis was limited to a maximum of 60 gunshots detected in each hour. Parks et al. (2012) reported average NARW gunshot rates from 74.9 calls $\mathrm{h}^{-1}$ for up to 7 callers, while Trygonis et al. (2013) reported an average gunshot production rate of 27.9 calls $\mathrm{h}^{-1}$ (derived from their Table II) from individuals in SAGs. They also reported an average rate of 110.9 calls $\mathrm{h}^{-1}$ for groups of 1 to 2 individuals, which is still half the rate seen for NPRW. With the exception of Matthews et al. (2001), higher gunshot call rates are more prevalent for solitary animals. Given that large SAGs are very uncommon for NPRW in the SEBS, it seems unlikely that the number of callers for our nonFF calling rates exceeds 1 to 2 individuals, so a very high gunshot call rate is to be expected.

The gunshot calling rate reported here is considerably higher than that reported for SRWs. Gunshots, called underwater slaps by Clark (1983), were produced at an estimated maximum rate of 6.5 calls $^{-1}$ (derived by Matthews et al. 2001). A very low SRW gunshot production rate was also seen by Webster et 
al. (2016) in a New Zealand calving ground; a rate of 2.4 calls $\mathrm{h}^{-1}$ was derived from their Table II using their reported $2.7 \%$ overall gunshot occurrence rate. Their recordings were made in the presence of an unknown number of groups ranging in size from single animals to large social groups.

Gunshot production by females has been documented in SRW (Clark 1983), and was more recently observed in NARW (E. Gerstein pers. comm.). Here, we document a female NPRW producing gunshots. The gunshots produced by the female in our study did not occur in regular bouts, and the average call rate was notably lower (i.e. less than one-third) than that of the males. Comparing call rates of the female NPRW in the current study to call rates from SRW (Clark 1983) suggest that female NPRW may produce gunshots considerably more frequently than their southern counterparts ( 54 calls h$^{-1}$ compared to a maximum possible 6 calls h$^{-1}$ [if all callers were females], respectively). However, the call rates obtained in the current study were obtained from 1 female and were potentially biased by the proximity of the vessel during the $\mathrm{FF}$, and may not be representative of all female NPRW.

The proportion of gunshots to the other call types in this study was very different than seen in other studies. Here, gunshots were detected over 50 times more frequently than upcalls, for a total of $97.7 \%$ of the total calls. This is in sharp contrast to the proportion of gunshots seen in other studies. For SRW in New Zealand, Webster et al. (2016) found that gunshots comprised just $2.7 \%$ of the total calls detected. However, gunshots made up $20 \%$ of the total calls detected for SRW in Argentina (Clark 1983). This latter figure is more similar to the $13 \%$ reported by Trygonis et al. (2013) for NARW SAGs during the calving season off the southeastern USA. Parks \& Tyack (2005) also reported gunshots comprising $16 \%$ of the total calls detected in the presence of NARW SAGs in the Bay of Fundy, although Matthews et al. (2001) found a higher percentage of gunshots (29\% of the total calls detected) for NARW on their feeding grounds. In addition, Van Parijs et al. (2009) noted that gunshot production for NARW varied over seasons and between geographic areas, with a significantly larger proportion $(75-80 \%$ of calls, estimated from their Fig. 2) of gunshots detected in their summering grounds in the Bay of Fundy compared to Cape Cod Bay or the Great South Channel that they occupy in the spring. This number is similar to, albeit lower than, the rate presented here for a similar time of year.

Although the period of data collection in this study corresponds with the peak times in NARW gunshot production, the ratio of gunshot production relative to upcalls or tonal calls is vastly different between the 2 species. Furthermore, the results from Parks \& Tyack (2005) and Matthews et al. (2001) showed that the proportion of gunshots in summer in the Bay of Fundy was half that of the other areas off the northeastern USA. Other reasons for the differences in the proportion of gunshot calling seen among the various SRW and NARW studies have already been discussed (Webster et al. 2016), and include differences in social context (which may be due to changes in social interactions throughout the seasons) as well as differences in focal group selection during field efforts. Although these differences may be due to various collection methods (short-term behavioral correlations vs. long-term moored data collection), they do suggest that interannual variation, whether in seasonal or geographic distribution, group composition, or social interaction, can also potentially affect the proportion of gunshots produced.

Unfortunately, the extreme paucity of data on the NPRW in other areas (e.g. the Gulf of Alaska) does not allow for a comparison of detection rates among different regions. However, for the SEBS, gunshots appear to be the predominant call type for this population during the summer/fall. While the lack of upcalls in the FFs may be due to vessel approaches altering vocal behavior, the calling rate of gunshots outside of the FFs was 53 times greater than that of upcalls. These findings are consistent with those of Rone et al. (2012) who reported that gunshots were detected 75 times more frequently than upcalls during aerial surveys where vessel activity was not a factor. Furthermore, for NPRW, the upcall rate reported here $\left(4.3\right.$ calls h$^{-1}$, range $\left.=0-36.0\right)$ is more than twice the 1.7 calls $^{-1}$ (range $=0.4-7.2$ ) rate reported by Marques et al. (2011). Munger et al. (2008) also reported a low overall number of NPRW upcall detections, with an average rate of approximately 2 upcalls $\mathrm{d}^{-1}$. However, during peak summer months (August and September, similar to this study), upcall rates reached over $500 \mathrm{~d}^{-1}\left(\sim 23 \mathrm{calls} \mathrm{h}^{-1}\right)$, similar to the values reported here.

It is unknown why the gunshot is produced with such great frequency in the SEBS. If this is predominantly a male-produced call type (e.g. Parks et al. 2005 , this study), then perhaps the 2:1 male to female ratio (Wade et al. 2011) for the NPRW results in more gunshots being produced than upcalls. However, this 2:1 ratio is not high enough to account for the disparity in detection rates between upcalls and gunshots found in this study and that of Rone et al. (2012). It is possible that, because of the extremely small popula- 
tion size and lack of calves (i.e. none have been seen since the Wade et al. (2006) sighting in 2004), the use of the upcall as a contact call (Clark 1983, Parks \& Tyack 2005) is not as necessary or frequent for this population. It seems most likely, however, that the predominance of solitary whales has inflated the gunshot rate for NPRW. Clark (1983) noted that solitary individuals tended to produce underwater slaps more frequently than groups. Parks et al. (2005) noted that lone NARW males produced a large number of gunshots, while individuals in SAGs often produced single gunshot calls. The same was seen in the present study; no NPRW SAGs were documented, while several lone males were the subject of FFs where gunshots were produced in large numbers.

It is important to note that although recordings were made over multiple days, at various times throughout the day, and from several different individuals, these calling rates were obtained from a very small sample size. Larger sample sizes are needed to confirm these findings, but may never be possible given the extremely low numbers of NPRW. As such, these calling rates are not representative of absolute NPRW calling activity, but may represent preliminary measures for future comparison.

\section{Possible function of the gunshot}

Currently, the function of the gunshot for this species is unknown, though it seems logical that it would serve similar functions as in other right whale populations. It may serve as a reproductive advertisement display, as has been suggested for male NARWs (Parks et al. 2005, 2011). Although very little is known about reproduction for this species, including breeding season and location, acoustic displays as reproductive advertisement are common in many baleen whale species, most notably humpback and bowhead whales (e.g. Payne \& McVay 1971, McSweeney et al. 1989, Cerchio et al. 2001, Stafford et al. 2008, Delarue et al. 2009, Tervo et al. 2009). The gunshot's function as a reproductive advertisement is also in agreement with the theory that it is predominantly produced by males. This is supported by the data presented here; although a female NPRW was documented producing gunshots, the calling rate was considerably lower than that of the males.

Female SRW have been reported to make gunshots, in what was suggested as an agonistic manner (Clark 1983). Gunshot production by female NARW has only recently been observed (E. Gerstein pers. comm.). It is unknown what function a gunshot call may serve for a female adult NPRW, although they may have been associated with maternal communication or perhaps indicators of stress (E. Gerstein pers. comm.). However, the gunshots analyzed in the current study, including those produced by the known female, were produced by solitary individuals, indicating that they are not used in any apparent close-range agonistic manner or maternal communications. For male NARWs, it is thought that gunshot production may also serve as a long-range agonistic signal toward other males, in a competitive or threatening manner (Parks et al. 2005). No apparent aggressive behavior or responses were observed during the FFs in our study. Similarly, Parks (2003) reported zero approaches of right whales in response to playbacks of gunshot calls. However, the function of the gunshot call as a long-range agonistic signal cannot be excluded.

Another possible function of the gunshot is its use in foraging. Currently, there is no evidence that lowfrequency broadband signals can be used to identify prey patches. However, the impulsive nature of the call could be used to obtain information on bottom topography, or potentially identify sufficiently concentrated patches of prey (Tyack \& Clark 2000). It is also possible that the gunshot may be used as an acoustic cue to alert other individuals to the presence of prey, similar to what was speculated by Croll et al. (2002) for fin whales. Baumgartner et al. (2013) studied the associations between NPRW, their sounds, and their zooplanktonic prey in the SEBS. One NPRW tagged in that study was also the same individual (NMML 24) that was focal followed later that same day (31 July 2009). These tagging results were unfortunately inconclusive; however, additional investigation into the gunshot's possible function in foraging is warranted. Regardless of its function(s), the gunshot clearly plays an important role in communication for this species, and should be included in all future acoustic analyses.

\section{Future plans and implications for conservation}

Passive acoustics is a valuable tool for monitoring this extremely small population, which in addition to being in a remote and challenging location, is often characterized by vessel avoidance and elusive behavior. However, in addition to long-term passive acoustic monitoring, concurrent visual/acoustic surveys are also critically important for NPRW. Very little is known about the full acoustic repertoire of the NPRW, and even less about the function(s) of the few known call types. Additional concurrent visual/ 
acoustic surveys, though difficult and expensive to conduct, are needed to continue to develop the full acoustic repertoire of the NPRW, particularly as they relate to behavioral states. More fine-scale acoustic analyses on the specific acoustic features of the gunshot, upcall, and other tonal calls would not only aid in correctly identifying and attributing calls to NPRW in areas outside its normal distribution, but also help to distinguish the NPRW from vocally similar species, such as humpback and bowhead whales, on longterm recorders. Also, if accurate calling rates are obtained, additional abundance estimates can be calculated from long-term passive acoustic recorders distributed throughout the Bering Sea shelf and compared to current population estimates (e.g. Marques et al. 2011, Wade et al. 2011). Comparative studies analyzing the specific differences in acoustic features of all NPRW call types as they compare to their better-understood NARW and SRW counterparts may aid in determining the function(s) of NPRW calls.

The results presented here suggest that the gunshot is the predominant call type for the NPRW in the summer months in the SEBS. It is essential that acoustic analyses of this Critically Endangered species or vocally similar species include the gunshot. The inclusion of this call type in NPRW analyses will greatly increase the detectability of the species, assist in distinguishing potentially ambiguous calls from other species, and allow for a more thorough and accurate analysis of their seasonal and spatial distribution.

Acknowledgements. We thank the field acoustic crew: Julia Hager, Holger Klinck, Karolin Klinck, Elizabeth Küsel, Don Ljungblad, and Francesco Scattorin. Thanks to Amy Kennedy for the individual NPRW information, and to the other visual observers during the surveys: Billy Adams, Dee Allen, Mark Baumgartner, Carter Esch, Yulia Ivaschenko, Nadine Lysiak, Tony Martinez, Sarah Mussoline, Desrae Reeb, Heather Riley, Oswaldo Vasquez, Suzanne Yin, and Alex Zerbini. Thanks to Captain Atle Remme and his crew of the FV 'Ocean Olympic' and FV 'Aquila,' and the crew of the NOAA ship 'Oscar Dyson'. Many thanks to Sue Moore, Dana Wright, and 3 anonymous reviewers for improving the manuscript. Thanks to Theresa Yost (Naval Operational Logistics Support Center), Jeffrey Leonhard, Todd Mequet, and Edward Rainey (Naval Surface Warfare Center, Crane Division), and Robin Fitch (I\&E Director Marine Science, Office of the Assistant Secretary of the Navy) for providing sonobuoys. Work was conducted under MML permit no. 14245. Funding and support was provided by the Bureau of Ocean Energy Management under Inter-Agency Agreement number M07RG13267. The findings and conclusions in the paper are those of the authors and do not necessarily represent the views of the National Marine Fisheries Service. Reference to trade names does not imply endorsement by the National Marine Fisheries Service or NOAA.

\section{LITERATURE CITED}

Awbrey FT, Thomas JA (1984) Measurements of sound propagation from several acoustic harassment devices. Final report to National Marine Fisheries Service, PO No. 84-JFA-00062. Hubbs-SeaWorld Research Institute, San Diego, CA

Barlow J, Taylor BL (2005) Estimates of sperm whale abundance in the northeastern temperate Pacific from a combined acoustic and visual survey. Mar Mamm Sci 21: 429-445

Baumann-Pickering S, Debich AJ, Trickey JT, Sirovic A and others (2013) Examining explosions in southern California and their potential impact on cetacean acoustic behavior. Scripps Institution of Oceanography, University of California San Diego and Southwest Fisheries Science Center, National Marine Fisheries Service, San Diego, CA

Baumgartner MF, Lysiak NSJ, Esch HC, Zerbini AN, Berchok CL, Clapham PJ (2013) Associations between North Pacific right whales and their zooplanktonic prey in the southeastern Bering Sea. Mar Ecol Prog Ser 490: 267-284

Bioacoustics Research Program (2011) Raven Pro: interactive sound analysis software (Version 1.4). The Cornell Lab of Ornithology, Ithaca, NY. www.birds.cornell.edu/ raven

Brodie PF (1993) Noise generated by the jaw actions of feeding fin whales. Can J Zool 71:2546-2550

* Burns JJ (1970) Remarks on the distribution and natural history of pagophilic pinnipeds in the Bering and Chukchi Seas. J Mammal 51:445-454

Cerchio S, Dahlheim M (2001) Variation in feeding vocalizations of humpback whales Megaptera novaeangliae from Southeast Alaska. Bioacoustics 11:277-295

Cerchio S, Jacobsen JK, Norris TF (2001) Temporal and geographical variation in songs of humpback whales, Megaptera novaeangliae: synchronous change in Hawaiian and Mexican breeding assemblages. Anim Behav 62: 313-329

Clapham PJ, Good C, Quinn SE, Reeves RR, Scarff JE, Brownell RL Jr (2004) Distribution of North Pacific right whales (Eubalaena japonica) as shown by 19th and 20th century whaling catch and sighting records. J Cetacean Res Manage 6:1-6

Clark CW (1982) The acoustic repertoire of the southern right whale, a quantitative analysis. Anim Behav 30: 1060-1071

Clark CW (1983) Acoustic communication and behavior of southern right whales (Eubalaena australis). In: Payne RS (ed) Communication and behavior of whales. American Association for the Advancement of Science Selected Symposium 76. Westview Press, Boulder, CO, p 163-198

Clark CW (1984) Acoustic communication and behavior of southern right whales, Eubalaena australis. Natl Geogr Soc Res Rep 17:897-907

Croll DA, Clark CW, Acevedo A, Tershy B, Flores S, Gedamke J, Urban J (2002) Bioacoustics: Only male fin whales sing loud songs. Nature 417:809

* Cummings WC, Fish J, Thompson P (1972) Sound production and other behavior of southern right whales, Eubalaena australis. Trans S Diego Soc Nat Hist 17:1-14

Cummings WC, Thompson PO, Fish JF (1974) Behavior of southern right whales: R/V Hero cruise 72-3. Antarct J US 9:33-38 
Delarue J, Laurinolli M, Martin B (2009) Bowhead whale (Balaena mysticetus) songs in the Chukchi Sea between October 2007 and May 2008. J Acoust Soc Am 126: 3319-3328

Dolphin WF (1987) Ventilation and dive patterns of humpback whales, Megaptera novaeangliae, on their Alaskan feeding grounds. Can J Zool 65:83-90

Dunlop RA, Noad MJ, Cato DH, Stokes D (2007) The social vocalization repertoire of east Australian migrating humpback whales (Megaptera novaeangliae). J Acoust Soc Am 122:2893-2905

Dunlop RA, Cato DH, Noad MJ (2008) Non-song acoustic communication in migrating humpback whales (Megaptera novaeangliae). Mar Mamm Sci 24:613-629

Fagen RM, Young DY (1978) Temporal patterns of behavior: durations, intervals, latencies, and sequences. In: Colgan PW (ed) Quantitative ethology. John Wiley and Sons, New York, NY, p 79-114

Fay FH (1982) Ecology and biology of the Pacific walrus, Odobenus rosmarus divergens Illiger. N Am Fauna 74: 1-279

* Hamilton EL (1980) Geoacoustic modeling of the sea floor. J Acoust Soc Am 68:1313-1340

*Hannay DE, Delarue J, Mouy X, Martin BS, Leary D, Oswald JN, Vallarta J (2013) Marine mammal acoustic detections in the northeastern Chukchi Sea, September 2007-July 2011. Cont Shelf Res 67:127-146

Ivashchenko YV, Clapham PJ (2012) Soviet catches of right whales Eubalaena japonica and bowhead whales Balaena mysticetus in the North Pacific Ocean and the Okhotsk Sea. Endang Species Res 18:201-217

Ivashchenko YV, Clapham PJ, Brownell RL Jr (in press) New data on Soviet blue and right whale catches in the North Pacific. J Cetacean Res Manage

Kaurinolli MH, Hay AE, Desharnais F, Taggart CT (2003) Localization of North Atlantic right whale sounds in the Bay of Fundy using a sonobuoy array. Mar Mamm Sci 19: 708-723

Marques TA, Munger L, Thomas L, Wiggins S, Hildebrand JA (2011) Estimating North Pacific right whale Eubalaena japonica density using passive acoustic cue counting. Endang Species Res 13:163-172

Martin P, Bateson P (1993) Measuring behavior: an introductory guide. Cambridge University Press, Cambridge

Matthews JN, Brown S, Gillespie D, Johnson M and others (2001) Vocalization rates of the North Atlantic right whale (Eubalaena glacialis). J Cetacean Res Manage 3:271-282

Matthews LP, McCordic JA, Parks SE (2014) Remote acoustic monitoring of North Atlantic right whales (Eubalaena glacialis) reveals seasonal and diel variations in acoustic behavior. PLOS ONE 9:e91367

McDonald MA, Moore SE (2002) Calls recorded from North Pacific right whales (Eubalaena japonica) in the eastern Bering Sea. J Cetacean Res Manage 4:261-266

*McSweeney DJ, Chu KC, Dolphin WF, Guinee LN (1989) North Pacific humpback whale songs: a comparison of southeast Alaskan feeding ground songs with Hawaiian wintering ground songs. Mar Mamm Sci 5:139-148

Medwin H, Clay CS (1998) Fundamentals of acoustical oceanography. Academic Press, San Diego, CA

Mellinger DK (2001) Ishmael 1.0 User's Guide. Tech Memo OAR PMEL-120. NOAA, Pacific Marine Environmental Laboratory, Seattle, WA and Cooperative Institute for Marine Resources Studies, Oregon State University, Hatfield Marine Science Center, Newport, OR
Mellinger DK (2004) A comparison of methods for detecting right whale calls. Can Acoust 32:55-65

Mellinger DK, Stafford KM, Moore SE, Munger LM, Fox CG (2004) Detection of North Pacific right whale (Eubalaena japonica) calls in the Gulf of Alaska. Mar Mamm Sci 20: 872-879

*Mellinger DK, Nieukirk SL, Matsumoto H, Heimlich SL, Dziak RP, Haxel J, Fowler M (2007) Seasonal occurrence of North Atlantic right whale (Eubalaena glacialis) vocalizations at two sites on the Scotian shelf. Mar Mamm Sci 23:856-867

*Miksis-Olds JL, Nystuen JA, Parks SE (2010) Detecting marine mammals with an adaptive sub-sampling recorder in the Bering Sea. Appl Acoust 71:1087-1092

Munger LM, Mellinger DK, Wiggins SM, Moore SE, Hildebrand JA (2005) Performance of spectrogram cross-correlation in detecting right whale calls in long-term recordings from the Bering Sea. Can Acoust 33:25-33

Munger LM, Wiggins SM, Moore SE, Hildebrand JA (2008) North Pacific right whale (Eubalaena japonica) seasonal and diel calling patterns from long-term acoustic recordings in the southeastern Bering Sea, 2000-2006. Mar Mamm Sci 24:795-814

Munger LM, Wiggins SM, Hildebrand JA (2011) North Pacific right whale up-call source levels and propagation distance on the southeastern Bering Sea shelf. J Acoust Soc Am 129:4047-4054

* Parks SE (2003) Response of North Atlantic right whales (Eubalaena glacialis) to playback of calls recorded from surface active groups in both the North and South Atlantic. Mar Mamm Sci 19:563-580

*Parks SE, Tyack PL (2005) Sound production by North Atlantic right whales (Eubalaena glacialis) in surface active groups. J Acoust Soc Am 117:3297-3306

* Parks SE, Hamilton PK, Kraus SD, Tyack PL (2005) The gunshot call sound produced by male North Atlantic right whales (Eubalaena glacialis) and its potential function in reproductive advertisement. Mar Mamm Sci 21:458-475

Parks SE, Searby A, Célérier A, Johnson MP, Nowacek DP, Tyack PL (2011) Sound production behavior of individual North Atlantic right whales: implications for passive acoustic monitoring. Endang Species Res 15:63-76

* Parks SE, Hotchkin CF, Cortopassi KA, Clark CW (2012) Characteristics of gunshot sound displays by North Atlantic right whales in the Bay of Fundy. J Acoust Soc Am 131:3173-3179

* Payne RS, McVay S (1971) Songs of humpback whales. Science 173:585-597

* Reilly SB, Bannister JL, Best PB, Brown M and others (2008) Eubalaena japonica. (Errata version published in 2016) The IUCN Red List of Threatened Species 2008: e.T 133706A98826605. http://dx.doi.org/10.2305/IUCN.UK. 2008.RLTS.T133706A3873095.en

* Rone BK, Berchok CL, Crance JL, Clapham PJ (2012) Using air-deployed passive sonobuoys to detect and locate critically endangered North Pacific right whales. Mar Mamm Sci 28:E528-E538

Scarff JE (2001) Preliminary estimates of whaling-induced mortality in the 19th century North Pacific right whale (Eubalaena japonicus) fishery, adjusting for struck-butlost whales and non-American whaling. J Cetacean Res Manag Spec Issue 2:261-268

Silber GK, Newcomer MW, Barros GJ (1988) Observations on the behavior and ventilation cycles of the vaquita, Phocoena sinus. Mar Mamm Sci 4:62-67 
Stafford KM, Moore SE, Laidre KL, Heide-Jørgensen MP (2008) Bowhead whale springtime song off West Greenland. J Acoust Soc Am 124:3315-3323

Stafford KM, Moore SE, Stabeno PJ, Holliday DV, Napp JM, Mellinger DK (2010) Biophysical ocean observation in the southeastern Bering Sea. Geophys Res Lett 37: L02606

Stimpert AK, Au WWL, Parks SE, Hurst T, Wiley DN (2011) Common humpback whale (Megaptera novaeangliae) sound types for passive acoustic monitoring. J Acoust Soc Am 129:476-482

Stirling I, Calvert W, Spencer C (1987) Evidence of stereotyped underwater vocalizations of male Atlantic walrus (Odobenus rosmarus rosmarus). Can J Zool 65:2311-2321

Tervo OM, Parks SE, Miller LA (2009) Seasonal changes in the vocal behavior of bowhead whales (Balaena mysticetus) in Disko Bay, Western Greenland. J Acoust Soc Am 126:1570-1580

Thode A, Bonnel J, Thieury M, Fagan A and others (2017) Using nonlinear time warping to estimate North Pacific Right Whale calling depths in the Bering Sea. J Acoust Soc Am 141:3059-3069

Thompson PO, Cummings WC, Ha SJ (1986) Sounds, source levels, and associated behavior of humpback whales, Southeast Alaska. J Acoust Soc Am 80:735-740

Trygonis V, Gerstein E, Moir J, McCulloch S (2013) Vocalization characteristics of North Atlantic right whale surface active groups in the calving habitat, southeastern United States. J Acoust Soc Am 134:4518-4531

Tyack PL, Clark CW (2000) Communication and acoustic behavior of dolphins and whales. In: Au WWL, Popper AN, Fay RR (eds) Hearing by whales and dolphins. Springer-Verlag, New York, NY, p 156-224

Urazghildiiev IR, Clark CW (2007) Acoustic detection of North Atlantic right whale contact calls using spectrogram-based statistics. J Acoust Soc Am 122:769-776

Van Parijs SM, Clark CW, Sousa-Lima RS, Parks SE, Rankin S, Risch D, Van Opzeeland IC (2009) Management and research applications of real-time and archival passive acoustic sensors over varying temporal and spatial scales. Mar Ecol Prog Ser 395:21-36

Editorial responsibility: Mike Noad, Gatton, Queensland, Australia
Vanderlaan ASM, Hay AE, Taggart CT (2003) Characterization of North Atlantic right whale (Eubalaena glacialis) sounds in the Bay of Fundy. IEEE J Oceanic Eng 28: 164-173

Wade P, Heide-Jørgensen MP, Shelden K, Barlow J and others (2006) Acoustic detection and satellite-tracking leads to discovery of rare concentration of endangered North Pacific right whales. Biol Lett 2:417-419

Wade PR, Kennedy A, LeDuc R, Barlow J and others (2011) The world's smallest whale population? Biol Lett 7:83-85

*Waite JM, Wynne K, Mellinger DK (2003) Documented sighting of a North Pacific right whale in the Gulf of Alaska and post-sighting acoustic monitoring. Northwest Nat 84 : 38-43

Watkins WA (1981) Activities and underwater sounds of fin whales. Sci Rep Whales Res Inst 33:83-117

*Watkins WA, Tyack PL, Moore KE, Bird JE (1987) The 20-Hz signals of finback whales (Balaenoptera physalus). J Acoust Soc Am 82:1901-1912

*Webster TA, Dawson SM, Rayment WJ, Parks SE, Van Parijs SM (2016) Quantitative analysis of the acoustic repertoire of southern right whales in New Zealand. J Acoust Soc Am 140:322-333

Wiggins SM, McDonald MA, Munger LM, Moore SE, Hildebrand JA (2004) Waveguide propagation allows range estimates for North Pacific right whales in the Bering Sea. Can Acoust 32:146-154

*Winn HE, Goodyear JD, Kenney RD, Petricig RO (1995) Dive patterns of tagged right whales in the Great South Channel. Cont Shelf Res 15:593-611

Wright DR (2001) Categorization of northern right whale, Eubalaena glacialis, sound. MA thesis, Boston University, Boston, MA

Würsig B, Clark CW (1993) Behavior. In: Burns J, Montague J, Cowles C (eds) The bowhead whale. Special Publication Number 2. Society for Marine Mammalogy, Lawrence, KS, p 157-199

Youngson BT, Darling JD (2016) The occurrence of pulse, 'knock' sounds amidst social/sexual behavior of gray whales (Eschrichtius robustus) off Vancouver Island. Mar Mamm Sci 32:1482-1490

Submitted: November 7, 2016; Accepted: June 30, 2017 Proofs received from author(s): September 7, 2017 